\section{Efficacy of Fungicide Treatments for Control of Anthracnose Canker in Young Cider Apple Trees in Western Washington}

\author{
Whitney J. Garton ${ }^{1}$, Mark Mazzola ${ }^{2}$, Travis R. Alexander ${ }^{1}$, \\ and Carol A. Miles ${ }^{1,3}$
}

AdDitional Index wORDs. Malus $\times$ domestica, Neofabraea species, zinc, copper sulfate, captan, thiophanate-methyl, pyraclostrobin plus boscalid

Summary. Anthracnose canker, caused by Neofabraea malicorticis, threatens the sustainability of cider apple (Malus $\times$ domestica) production in the maritime climate of western Washington. In the short-term, the disease reduces overall orchard productivity and in the long-term it reduces an orchard's economic life span. The disease is difficult to manage using cultural practices, and information on fungicide efficacy is limited and contradictory. To address this situation, a 2 -year study was conducted to evaluate efficacy of zinc $(4.49 \mathrm{lb} /$ acre $)$, basic copper sulfate $(2.49 \mathrm{lb} /$ acre), captan $(2.94 \mathrm{lb} /$ acre $)$, thiophanate-methyl (0.69 lb/acre), pyraclostrobin plus boscalid $(0.38 \mathrm{lb} / \mathrm{acre})$, and combinations of these fungicides to manage anthracnose canker infection in young cider apple trees cultivated in a maritime climate. Trees used in the first year of the study (2016) were found to be infected by anthracnose canker on receipt, so the first year was a measure of disease control and the second year (2017) was a measure of disease prevention. In 2016, when fungicide treatments were applied every 3 weeks from March through October, none of the treatments evaluated inhibited the development of new infections or the expansion of existing cankers $(77 \%$ increase in canker size on average for all treatments). In 2017, when fungicide treatments were applied every 3 weeks from February through April, two to three new cankers were observed 3 weeks after final treatment application for all treatments. Results from this study demonstrate that the current fungicides recommended for control of anthracnose canker are not reliably effective in the orchard environment of northwest Washington. Future studies should assess the fungicides evaluated in this study applied in rotation with additional systemic fungicides.

A

nthracnose canker, caused by Neofabraea malicorticis, induces tree cankers that can kill

Received for publication 2 Oct. 2018. Accepted for publication 7 Nov. 2018.

Published online 4 February 2019

Funding and support for this project is gratefully acknowledged from Washington State University Extension, Washington State Commission on Pesticide Registration, Northwest Cider Association, Northwest Agricultural Research Foundation, and Washington State Project WN00427-Acc. No. 1000194 .

The mention of a trademark, proprietary product, or company does not constitute a guarantee or warranty of the product by the USDA-ARS and does not imply its approval to the exclusion of other products or companies that also may be suitable.

${ }^{1}$ Department of Horticulture, Washington State University Northwestern Washington Research and Extension Center, 16650 State Route 546, Mount Vernon, WA 98273

${ }^{2}$ U.S. Department of Agriculture-Agricultural Research Service, Physiology and Pathology of Tree Fruits Research Laboratory, 1104 N. Western Avenue, Wenatchee, WA 98801

${ }^{3}$ Corresponding author. E-mail: milesc@ $@_{w s u}$.edu.

This is an open access article distributed under the CC BY-NC-ND license (https://creativecommons.org/ licenses/by-nc-nd/4.0/).

https://doi.org/10.21273/HORTTECH04201-18 newly planted cider apple trees west of the Cascade Mountains in the U.S. Pacific Northwest (PNW) (Garton et al., 2018a; Rahe, 1997a). N. malicorticis can infect intact bark tissue, and most infections occur through the lenticels (Cordley, 1900; Kienholz, 1939). Acervuli (asexual fruiting bodies) form on mature cankers in midsummer to late-autumn, producing conidia (asexual spores) that cause new N. malicorticis infections (Creemers, 2014) in autumn and winter during mild, moist weather (Davidson and Byther, 1992; Rahe, 2010). Apothecia (sexual fruiting bodies) may develop on overwintering cankers, and ascospores (sexual spores) may cause new N. malicorticis infections in the spring (Powell et al., 1970; Rahe, 1997a). Canker progression is slow or ceases in the winter, is more rapid in the spring, and by early summer, cankers are fully developed (Creemers, 2014; Davidson and Byther, 1992). Although N. malicorticis is the primary pathogen that induces anthracnose canker, additional species, including Pblyctema vagabunda (synonym Neofabraea alba) and Neofabraea kienholzii have also been implicated as the cause of this disease (Zang et al., 2011).

Populations of $N$. malicorticis have been reported throughout North America, Africa (Zimbabwe), Oceania (Australia and New Zealand), and Europe (European and Mediterranean Plant Protection Organization, 2017), with disease severity observed to be highest in the maritime PNW. Environmental conditions of the maritime PNW favor growth and spore dissemination of N. malicorticis yearround (Hortová et al., 2014; Kienholz, 1939; Miller, 1932; Senula, 1985; Spotts and Peters, 1982). The temperature in northwest Washington, for example, is $14{ }^{\circ} \mathrm{C}$ on average during the growing season (April-October) and $6{ }^{\circ} \mathrm{C}$ during the dormant season (November-March) (Washington State University, 2017). Relative humidity is $73 \%$ to $82 \%$ on average during the growing season and $82 \%$ to $91 \%$ during the dormant season, while $76 \mathrm{~mm}$ precipitation occurs on average during the growing season and $101 \mathrm{~mm}$ occurs during the dormant season. Solar radiation in the area also tends to be moderate, with $506 \mathrm{MJ} \cdot \mathrm{m}^{-2}$ during the growing season on average, and $157 \mathrm{MJ} \cdot \mathrm{m}^{-2}$ during the dormant season.

Cider apple growers in western Washington use several measures to control anthracnose canker, including excising cankers from infected wood and applying fungicides before autumn rains (Pscheidt and Ocamb,

\begin{tabular}{llll}
\hline $\begin{array}{l}\text { Units } \\
\text { To convert U.S. to SI, } \\
\text { multiply by }\end{array}$ & U.S. unit & SI unit & $\begin{array}{l}\text { To convert SI to U.S., } \\
\text { multiply by }\end{array}$ \\
\hline 0.3048 & $\mathrm{ft}$ & $\mathrm{m}$ & 3.2808 \\
3.7854 & gal & $\mathrm{L}$ & 0.2642 \\
25.4 & inch(es $)$ & $\mathrm{mm}$ & 0.0394 \\
6.4516 & inch ${ }^{2}$ & $\mathrm{~cm}^{2}$ & 0.1550 \\
0.0418 & langley(s) & ${\mathrm{MJ} \cdot \mathrm{m}^{-2}}^{-23.9006}$ \\
1.1209 & lb/acre & $\mathrm{kg} \cdot \mathrm{ha}^{-1}$ & 0.8922 \\
1.6093 & mile(s) & $\mathrm{km}$ & 0.6214 \\
$\left({ }^{\circ} \mathrm{F}-32\right) \div 1.8$ & ${ }^{\circ} \mathrm{F}$ & ${ }^{\circ} \mathrm{C}$ & $\left({ }^{\circ} \mathrm{C} \times 1.8\right)+32$
\end{tabular}


2017). Zinc [Fungicide Resistance Action Committee (FRAC) code M03], captan (FRAC code M04), and copper-based products (FRAC code M01) are the common fungicides applied in PNW cider apple orchards. However, Garton et al. (2018b) found new N. malicorticis infections of susceptible hosts to occur after applying many of these common fungicide treatments on cider apple trees in northwest Washington. Further, in commercial orchards, these fungicide treatments have not provided significant disease control, as orchards continue to be abandoned or torn out within 4 years of symptom appearance (Garton et al., 2018a; Rahe, 1997a).

Research on fungicide efficacy for control of anthracnose canker on apple trees in general is limited and contradictory. In an orchard study in western Washington, Byther (1986) found a $50 \%$ reduction in the number of new canker infections to develop on trees when zinc and basic copper sulfate were applied in mid-October and again in mid-February. In an in vitro study in British Columbia, Canada, Rahe (1997a) found captan to be moderately toxic to $N$. malicorticis, whereas copper-based fungicides were nontoxic to the fungus. Rahe (1997b) also investigated efficacy of thiophanate-methyl (FRAC code 1) and thiram (FRAC code M3) for control of anthracnose canker on trees in British Columbia and found the fungicides to be ineffective when applied biweekly from mid-August through late October. Research in central Washington has tested fungicide efficacy to control four Neofabraea species (N. alba, N. malicorticis, $N$. perennans, and $N$. kienholzii) that cause bull's-eye rot on pome fruit (Rosaceae), and found thiabendazole (FRAC code 1), thiophanate-methyl, pyrimethanil (FRAC code 9), and pyraclostrobin plus boscalid (FRAC codes 11 and 7 , respectively) to control all Neofabraea species, whereas zinc did not provide effective control of $N$. malicorticis but copper sulfate did (Spotts et al., 2009). Creemers (2014) recommended the use of chemistries such as quinone outside inhibitors (FRAC code 11) for controlling anthracnose canker, but Aguilar et al. (2018) reported such chemistries as ineffective in controlling diseases incited by Neofabraea species. The objective of this study was to better understand the efficacy of current fungicides recommended for control of anthracnose canker, specifically, zinc, basic copper sulfate, captan, thiophanate-methyl, and pyraclostrobin plus boscalid, on cider apple trees in the maritime PNW.

\section{Materials and methods}

Orchard site. This study was conducted in 2016 and 2017 in a cider apple research orchard at Washington State University (WSU) Northwestern Washington Research and Extension Center (NWREC), in Mount Vernon, WA. Weather data (mean air temperature, relative humidity, total precipitation, and solar radiation) were recorded every $5 \mathrm{~s}$ and summarized every $15 \mathrm{~min}$ by a weather station located $\approx 0.4$ miles from the orchard (WSU, 2017). Plots were established in a randomized complete block design with five assigned singletree replicates per fungicide treatment. Both years, experimental treatments were applied to newly planted trees that were sourced from commercial nurseries. In 2016, trees used in the study were 'Tompkins King' on 'MallingMerton 106' (MM.106) that were budded at a local nursery in Aug. 2014 , received at WSU NWREC in early Nov. 2015, and were established in pots in a screen house to minimize potential for $N$. malicorticis infection from the orchard before onset of the experiment; however, trees were found to have early anthracnose canker infection on receipt. In 2017, 'Ashmead's Kernel' on 'Geneva 11' were sourced from a commercial nursery outside of the PNW for this study. Trees were nursery-budded in Aug. 2015 and received at WSU NWREC the end of Nov. 2016. On receipt, trees were inspected visually and found to be clean of anthracnose cankers. Trees were established in pots in a screen house to prevent $N$. malicorticis infection from the orchard before onset of the experiment. Trees were planted into different orchard blocks each year; in 2016, spacing was $10 \mathrm{ft}$ in-row and $13 \mathrm{ft}$ between rows, and in 2017, spacing was $3 \mathrm{ft}$ in-row and $13 \mathrm{ft}$ between rows. Both years, trees were staked (bamboo in 2016 and metal in 2017) for support, and managed pursuant to the principles of a tall spindle orchard system. Drip irrigation tape was placed directly on the soil surface, and in 2016, irrigation was applied twice a week for $4 \mathrm{~h}$ at a rate of $0.5 \mathrm{gal} / \mathrm{h}$ from early June to early September (Moulton et al., 2010). In 2017, irrigation was not applied, as there was adequate precipitation throughout the study period, which ended in May.

Fungicide treatments. In 2016 , trees were planted in the orchard in March, and a control treatment (no fungicide) plus four fungicide treatments were applied: $4.49 \mathrm{lb} /$ acre zinc (Ziram $76 \mathrm{DF}$; United Phosphorus, King of Prussia, PA), $0.38 \mathrm{lb} /$ acre pyraclostrobin plus boscalid (Pristine; BASF Corp., Research Triangle Park, NC), 0.69 $\mathrm{lb} /$ acre thiophanate-methyl (Topsin $\mathrm{M}$, United Phosphorus), and 2.49 $\mathrm{lb} /$ acre basic copper sulfate (Bonide Copper; W. Neudorff, Emmerthal, Germany). Treatments were first applied on 18 Mar. and were repeated every 3 weeks until 21 Oct. (13 applications in total). Application of zinc was ended in September (11 applications in total) due to the treatment inducing symptoms of phytotoxicity (premature leaf drop and leaf burn). Although this number of applications of the same fungicide is not a recommended practice, the aim of this test was to discern if these chemistries had any activity against the pathogen in an orchard setting throughout the summer. In 2017, trees were moved outside the screen house in treatment groups, fungicide applications were performed, and after the restricted entry interval for each fungicide treatment passed, the trees were planted into the orchard. A control treatment (no fungicide) plus eight fungicide treatments were applied: $4.49 \mathrm{lb} /$ acre zinc (Ziram 76 DF), $0.38 \mathrm{lb} /$ acre pyraclostrobin plus boscalid (Pristine), $0.69 \mathrm{lb} /$ acre thiophanate-methyl (Topsin M), 2.94 lb/acre captan (Captan 80 WDG; Arysta LifeScience North America Corp., Cary, NC); $4.49 \mathrm{lb}$ /acre zinc + $0.69 \mathrm{lb} /$ acre thiophanate-methyl, $4.49 \mathrm{lb} /$ acre zinc $+0.38 \mathrm{lb} /$ acre pyraclostrobin plus boscalid, 2.94 $\mathrm{lb} /$ acre captan $+0.69 \mathrm{lb} /$ acre thiophanate-methyl, and $2.94 \mathrm{lb} /$ acre captan $+0.38 \mathrm{lb} /$ acre pyraclostrobin plus boscalid. Treatments were first applied on $17 \mathrm{Feb}$. and were repeated every 3 weeks until 21 Apr. (four applications in total), and treatments with two fungicides were alternated in the order in which they were listed. Treatment application in 2017 
continued until trees in all treatments showed symptoms of infection. Both years, fungicide treatments plus surfactant (R-1l Spreader Activator; Wilbur-Ellis Co., Aurora, CO) were applied to the entire tree in each treatment group, using a hand-pump sprayer equipped with a cone nozzle (SureSpray; Chapin International, Batavia, NY) until runoff. Applications in the orchard were made with a plastic screen $(6 \times 6 \mathrm{ft})$ placed between trees at the time of application to prevent chemical drift between trees.

Canker size. In 2016, three anthracnose cankers were randomly selected per tree for measurement throughout the experiment to compare fungicide treatment effects. The length and width of each canker were measured pretreatment and 2 months after the initial treatment application. Thereafter, canker length and width were measured once every month until 16 Sept. for the zinc treatment and 11 Nov. for all other treatments. Canker size was calculated for each date using an equation for an ellipse [PI function (Microsoft Excel 2013; Microsoft, Redmond, WA)], and size was averaged for the three canker subsamples per treatment replicate. Canker size was not measured in 2017, as newly formed cankers had poorly defined margins that prevented an accurate assessment of size.

CANKER N U M B ER A N D INCIDENCE. In 2016, the total number of cankers present on each tree was recorded before treatment application, and every 3 weeks after the initial treatment application until 11 Nov., which was 3 weeks after the final treatment application. In 2017, trees were visually inspected for cankers and incidence (present or absent) was recorded before fungicide application and every 3 weeks thereafter until 12 May, which was 3 weeks after the final application.

DISEASE SYMPTOM SEVERITY. On 14 Feb. 2017, which was 4 to 7 months after final fungicide application, disease severity was rated visually on cankers treated in 2016. Following Rahe (2010), healthy tissue beyond the perceived margin of infection was removed, as the pathogen may reside in this tissue. Following Garton et al. (2018b), the resulting excisions were $1 \mathrm{~mm}$ to $3 \mathrm{~mm}$ beyond the original canker margins, but cambium tissue was present throughout the excision zone. The amount of exposed cambium tissue that exhibited dark brown streaking was then visually rated on a scale of 0 to 5 as follows: $0=$ no streaking, $1=1 \%$ to $20 \%$ streaking, $2=21 \%$ to $40 \%$ streaking, $3=41 \%$ to $60 \%$ streaking, $4=61 \%$ to $80 \%$ streaking, and $5=$ more than $81 \%$ streaking. Symptomatic tissue was collected from the treated cankers of all five trees per treatment, for pathogen isolation and identification. Tissue was surface sterilized in $0.5 \%$ sodium hypochlorite and rinsed with sterile distilled water, then small sections were plated onto potato dextrose agar [PDA (Difco; Becton, Dickinson and Co., Sparks, MD)] amended with chloramphenicol (Sigma-Aldrich Co., St. Louis, MO). Plates were incubated at 68 to $72{ }^{\circ} \mathrm{F}$, and cultures were transferred to fresh PDA weekly.

Data analysis. The assumptions of normality and homogeneity of variances were assessed in all cases using the Shapiro-Wilk test $(\mathrm{W}>$ $0.80)$ and the Levene test $(\alpha=$ $0.05)$, respectively. Size of the canker, total number of new cankers to develop on each tree, and disease severity data were subjected to repeated measures analysis, time modeled as a factor, block as a random effect, and multiple comparison test within each date performed using Tukey's honestly significant difference at a $5 \%$ level of significance in JMP (version 12.0 for Windows; SAS Institute, Cary, NC). For tissue streaking rating, an ordinal logistic model was used. Treatment means for the number of new cankers and tissue streaking were compared using Student's $t$ test at a $5 \%$ level of significance.

\section{Results}

Climate. Daily mean air temperature in 2016 was $10.6{ }^{\circ} \mathrm{C}$ from March through April, and $15.0{ }^{\circ} \mathrm{C}$ from May through October (Fig. 1). In 2017, daily mean air temperature was $7.5{ }^{\circ} \mathrm{C}$ from February through April (Fig. 2). Daily mean relative humidity was similar both years, $78 \%$ in 2016 and $80 \%$ in 2017 (Figs. 1-2). Mean precipitation in 2016 was $2.5 \mathrm{~mm}$ March through April and $1.9 \mathrm{~mm}$ from May through October, whereas in 2017, mean precipitation was $3.2 \mathrm{~mm}$ February through April (Figs. 1-2).

Canker size. In 2016, average canker size was $0.24 \mathrm{~cm}^{2}$ pretreatment and there was no significant difference in initial size of cankers before treatment application $[P=$ 0.88 (Fig. 3)]. Canker size significantly increased over time $(P<$ $0.0001)$, but did not differ among fungicide treatments over time $(P=$ $0.72)$. Two months after the initial application, canker size increased by $25 \%$ on average for all treatments compared with the pretreatment size, reaching an average canker size of 0.3 $\mathrm{cm}^{2}$ for all treatments. By the end of the experiment, 8 months after the initial application of all treatments, canker size had increased $77 \%$ on average for all treatments compared with the pretreatment size, reaching an average canker size of $0.45 \mathrm{~cm}^{2}$. At the end of the study, the average size

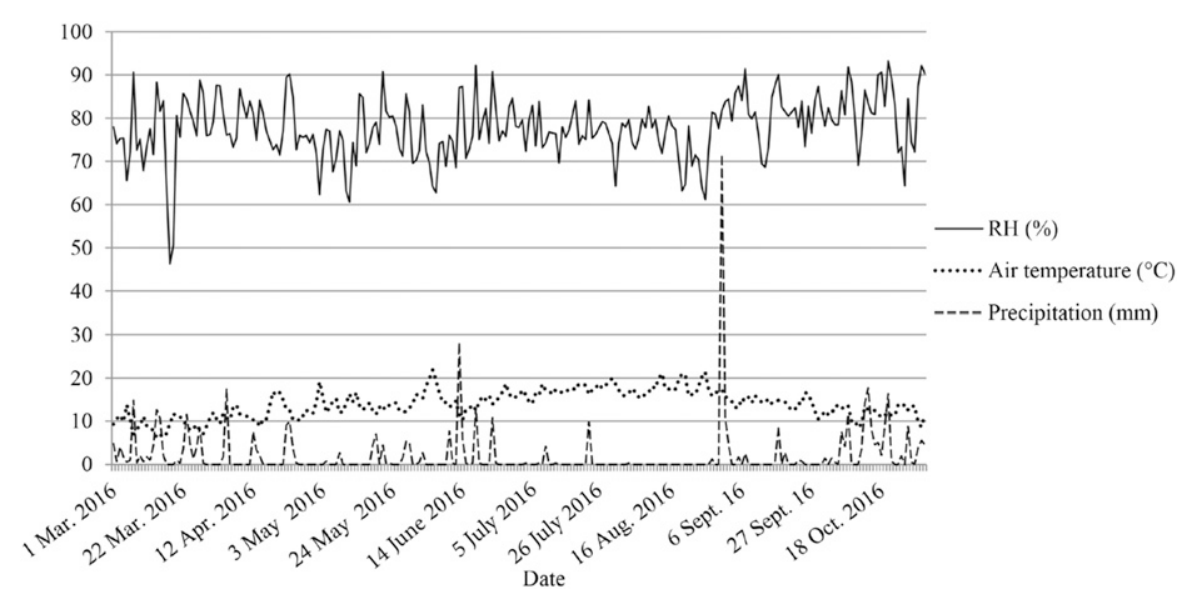

Fig. 1. Mean daily air temperature, relative humidity $(\mathrm{RH})$, and precipitation at Washington State University Northwestern Washington Research and Extension Center in Mount Vernon, WA, during the 2016 study of fungicide efficacy in controlling apple anthracnose canker; $\left(1.8 \times{ }^{\circ} \mathrm{C}\right)+32={ }^{\circ} \mathrm{F}, 1 \mathrm{~mm}=0.0394$ inch. 


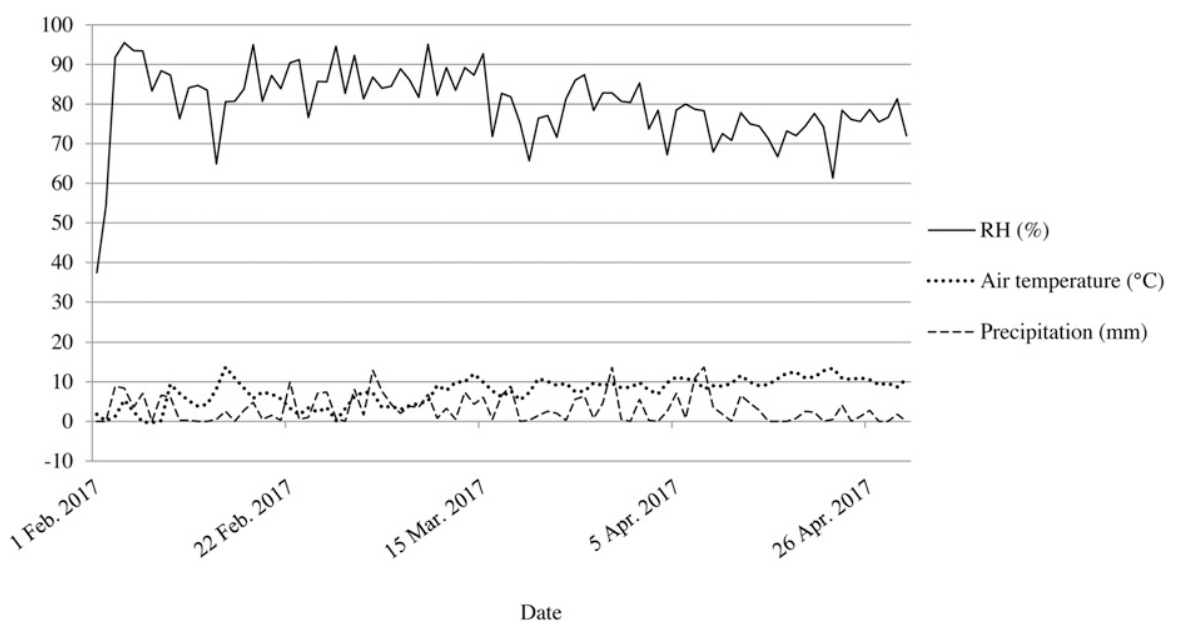

Fig. 2. Mean daily air temperature, relative humidity $(\mathrm{RH})$, and precipitation at Washington State University Northwestern Washington Research and Extension Center in Mount Vernon, WA, during the 2017 study of fungicide efficacy in preventing apple anthracnose canker infection; $\left(1.8 \times{ }^{\circ} \mathrm{C}\right)+32={ }^{\circ} \mathrm{F}, 1 \mathrm{~mm}=$ 0.0394 inch.

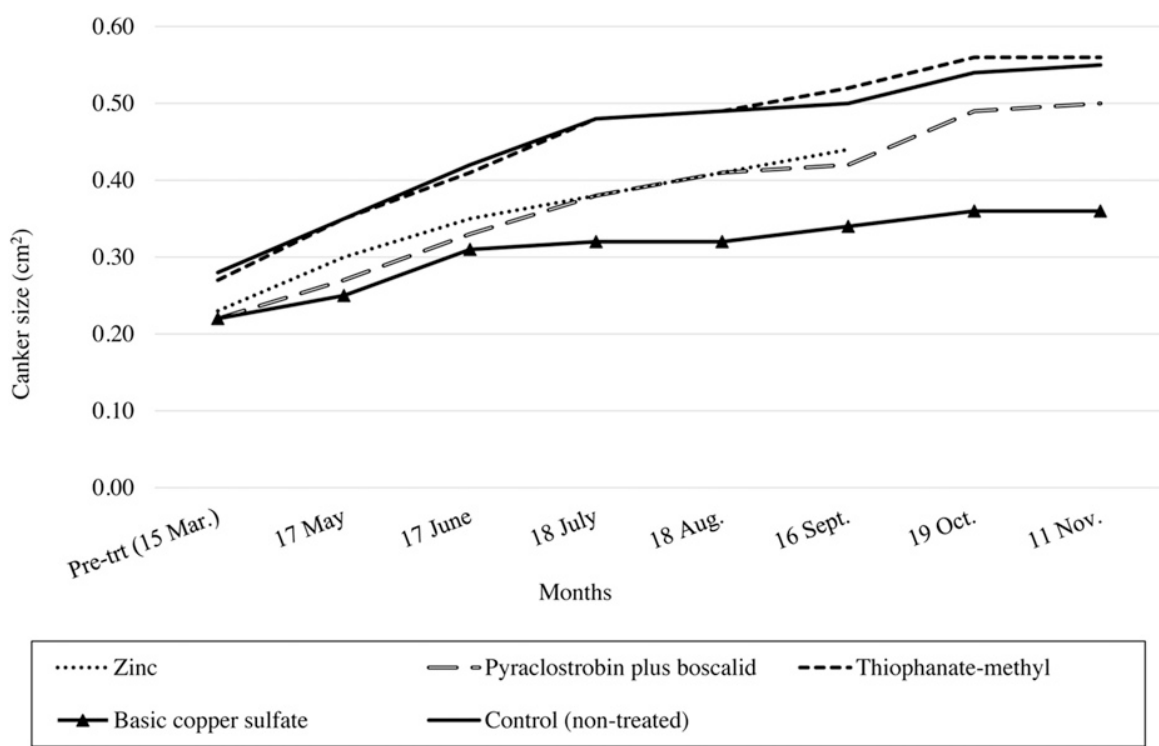

Fig. 3. Effect of fungicide treatments on canker size incited by Neofabraea malicorticis on 'Tompkins King' cider apple trees in 2016. Fungicide treatments were applied every 3 weeks until 21 Oct., but the zinc treatment was ended in September due to plant toxicity issues. Canker size increased significantly over time $(P<0.0001)$, but there were no significant differences in canker size among treatments $(P<0.72)$, based on repeated measures analysis followed by Tukey's honestly significant difference test at a $5 \%$ level of significance; $1 \mathrm{~cm}^{2}=0.1550$ inch $^{2}$. Pre-trt $=$ pretreatment.

of cankers on trees treated with basic copper sulfate, zinc, and pyraclostrobin plus boscalid were numerically smaller than cankers treated with thiophanate-methyl and the untreated cankers (controls), but not significantly.

Number of CANKers. In 2016, 3 weeks after the final treatment application, there were two to three new cankers per tree in all treatments, and plus boscalid, and captan plus thiophanate-methyl; cankers were first observed in these three treatments 9 weeks after the initial application $(\mathrm{Ta}$ ble 2). The total number of cankers observed on 12 May, 3 weeks after the final treatment application, ranged from one to three per tree and did not differ among treatments $[P=$ 0.88 (Table 1)].

Disease SYMPTOM SEVERITY. In 2017, dark brown streaks indicative of the disease were observed in the cambium tissue below the treated cankers 4 to 7 months after the final application of all treatments. Disease severity was moderate ( $20 \%$ to $40 \%)$ for all treatments, and there was no significant treatment difference $[P=$ 0.65 (Table 1)]. N. malicorticis was not successfully isolated from symptomatic cambium tissue; however, symptom morphology aligned with descriptions of $N$. malicorticis by Byther (1986) and Rahe (2010).

\section{Discussion}

Average air temperature, relative humidity, and precipitation were favorable for the dissemination and development of $N$. malicorticis both years. This finding is similar to Garton et al. (2018b) at the same location, and aligns with previous reports that indicate mild temperatures ranging from 0 to $22{ }^{\circ} \mathrm{C}$ in combination with a moist environment are favorable for disease development by $N$. malicorticis (Cordley, 1900; Hortová et al., 2014; Kienholz, 1939; Spotts and Peters, 1982).

In the maritime PNW, zinc, captan, and copper-based fungicides have been recommended for control of anthracnose canker in orchards (Pscheidt and Ocamb, 2017); however, none of these fungicide treatments prevented infections by $N$. malicorticis in this study when applications were made every 3 weeks from February through October. Although captan in combination with the systemic fungicide pyraclostrobin plus boscalid was expected to provide a good level of control, this was not the case in this study. Better control was provided when zinc was alternated with pyraclostrobin plus boscalid, or when captan was alternated with thiophanatemethyl, or when thiophanate-methyl was applied alone (although this is not recommended due to potential for creating pathogen resistance). Efficacy of 
Table 1. The number of new cankers observed 11 Nov. 2016 on 'Tompkins King' apple trees and 12 May 2017 on 'Ashmead's Kernel' apple trees (3 weeks after final treatment application both years), and disease severity under the canker on 'Ashmead's Kernel' apple trees as rated 14 Feb. 2017 (4 to 7 months after the final treatment application).

\begin{tabular}{|c|c|c|c|}
\hline \multirow[b]{2}{*}{ Active ingredient(s) } & \multicolumn{2}{|c|}{ New cankers (no.) } & \multirow{2}{*}{$\begin{array}{c}\text { Disease severity } \\
(1-5 \text { scale })^{\mathrm{z}} \\
2017\end{array}$} \\
\hline & 2016 & 2017 & \\
\hline Zinc & $3^{y}$ & 1 & 2 \\
\hline Pyraclostrobin + boscalid & 3 & 2 & 2 \\
\hline Thiophanate-methyl & 2 & 2 & 2 \\
\hline Basic copper sulfate & 2 & $-^{\mathrm{x}}$ & 2 \\
\hline Captan & - & 2 & - \\
\hline Zinc + thiophanate-methyl & - & 3 & - \\
\hline Zinc + pyraclostrobin + boscalid & - & 2 & - \\
\hline Captan + thiophanate-methyl & - & 1 & - \\
\hline Captan + pyraclostrobin + boscalid & - & 2 & - \\
\hline Control (nontreated) & 3 & 3 & 2 \\
\hline$P$ & 0.50 & 0.88 & 0.65 \\
\hline
\end{tabular}

${ }^{\mathrm{z}}$ Disease severity rated on a scale of 0 to 5 , where $0=$ no discoloration beyond margin, $1=1 \%$ to $20 \%$ discoloration beyond margin, $2=21 \%$ to $40 \%$ discoloration beyond margin, $3=41 \%$ to $60 \%$ discoloration beyond margin, $4=$ $61 \%$ to $80 \%$ discoloration beyond margin, and $5=$ more than $81 \%$ discoloration beyond margin.

${ }^{\mathrm{y}}$ Treatment means for the number of new cankers and disease severity were compared using Student's $t$ test at a $5 \%$ level of significance.

${ }^{\mathrm{x}}$ The $(-)$ symbol indicates treatment was not included

Table 2. Canker incidence pretreatment (pre-trt) and 3 to 12 weeks after initial fungicide treatment application to 'Ashmead's Kernel' apple trees in 2017 to test prevention of anthracnose canker; $(\mathrm{Y})$ cankers present, $(\mathrm{N})$ cankers not present.

\section{Canker incidence ${ }^{\mathrm{z}}$}

Treatment

17 Feb. 9 Mar. 30 Mar. 20 Apr. 12 May

Zinc

Pyraclostrobin + boscalid

(Pre-trt) (week 3) (week 6) (week 9) (week 12)

Thiophanate-methyl

Captan

Zinc + thiophanate-methyl

Zinc + pyraclostrobin + boscalid

Captan + thiophanate-methyl

Captan + pyraclostrobin + boscalid

Control (nontreated)

\begin{tabular}{lllll}
$\mathrm{N}$ & $\mathrm{Y}$ & $\mathrm{Y}$ & $\mathrm{Y}$ & $\mathrm{Y}$ \\
$\mathrm{N}$ & $\mathrm{Y}$ & $\mathrm{Y}$ & $\mathrm{Y}$ & $\mathrm{Y}$ \\
$\mathrm{N}$ & $\mathrm{N}$ & $\mathrm{N}$ & $\mathrm{Y}$ & $\mathrm{Y}$ \\
$\mathrm{N}$ & $\mathrm{Y}$ & $\mathrm{Y}$ & $\mathrm{Y}$ & $\mathrm{Y}$ \\
$\mathrm{N}$ & $\mathrm{Y}$ & $\mathrm{Y}$ & $\mathrm{Y}$ & $\mathrm{Y}$ \\
$\mathrm{N}$ & $\mathrm{N}$ & $\mathrm{N}$ & $\mathrm{Y}$ & $\mathrm{Y}$ \\
$\mathrm{N}$ & $\mathrm{N}$ & $\mathrm{N}$ & $\mathrm{Y}$ & $\mathrm{Y}$ \\
$\mathrm{N}$ & $\mathrm{Y}$ & $\mathrm{Y}$ & $\mathrm{Y}$ & $\mathrm{Y}$ \\
$\mathrm{N}$ & $\mathrm{Y}$ & $\mathrm{Y}$ & $\mathrm{Y}$ & $\mathrm{Y}$ \\
\hline
\end{tabular}

${ }^{\mathrm{z}}$ Each data point represents the mean canker incidence of five replicates.

zinc or captan as a preventive treatment against anthracnose canker may be further enhanced if it is alternated with a systemic fungicide that has proven effective against Neofabraea species, such as thiabendazole or pyrimethanil (Spotts et al., 2009); however, the efficacies of these combinations need to be evaluated.

Systemic fungicides, such as pyraclostrobin plus boscalid and thiophanate-methyl, can penetrate plant tissues and redistribute to nontreated tissue through the vascular system (Hewitt, 1998). In a previous study, pyraclostrobin plus boscalid was effective at controlling bull's-eye rot on apple fruit caused by all species of Neofabraea (Spotts et al., 2009). In the current study, however, repeated application of pyraclostrobin plus boscalid did not prevent the development of new infections on cider apple bark. It is possible that pathogen resistance occurred due to repeated applications of single fungicide chemistries in 2016. However, it is unlikely this affected 2017 results, as the two studies were carried out in different orchard blocks, each year the treatments were applied to only five singletree replicates within the orchard (an entire block of trees did not receive an individual treatment), and different chemistries were used each year.

\section{Conclusion}

This is the first orchard study that tested the efficacy of currently available fungicides for the control of N. malicorticis infections on apple trees. Until recently, most fungicide assays against $N$. malicorticis have been carried out only in vitro or for the control of bull's-eye rot on apple fruit. In the current study, no fungicides showed consistent efficacy at controlling $N$. malicorticis infections on apple trees. As each fungicide showed only modest efficacy toward either limiting canker expansion and/ or preventing the development of new infections, further work should use an in vitro bioassay to examine pathogen sensitivity/resistance to the fungicides evaluated. Neofabraea species appear to exhibit sensitivity to individual fungicides and may develop resistance to particular active ingredients or modes of action, which have already been detected in certain populations of Neofabraea species (Spotts et al., 2009; Weber and Palm, 2010). Furthermore, additional fungicides, or combining or alternating fungicides with different modes of action, should be tested, as none of the fungicides included in this study showed high efficacy.

Under the climate conditions in the maritime PNW, a year-round disease management program may be required for successful management of Neofabraea species. This study also demonstrated that cider apple trees produced commercially in the region can be infected by anthracnose canker in the nursery; thus, a commercial source from outside the region may be needed to avoid introducing infection into a new orchard. With the challenges faced in attempting to manage anthracnose canker using the currently available fungicides, cultivar and rootstock susceptibility and resistance or tolerance to anthracnose canker also should be evaluated.

\section{Literature cited}

Aguilar, C., M. Mazzola, and C. Xiao. 2018. Control of bull's-eye rot of apple caused by Neofabraea perennans and Neofabraea kienholzii using pre- and postharvest fungicides. Plant Dis. 102:905-910.

Byther, R.S. 1986. Apple anthracnose. Western Cascade Tree Fruit Nwsl. p. 6-8.

Cordley, A.B. 1900. Apple tree anthracnose: A new fungus disease. Oregon Agr. Expt. Sta. Bul. 60:1-8.

Creemers, P. 2014. Anthracnose canker and perennial cankers, p. 51-53. In: T. Sutton, H. Aldwinckle, A. Agnello, and J. 
Walgenbach (eds.). 2014. Compendium of apple and pear diseases. 2nd ed. APS Press, St. Paul, MN.

Davidson, R. and R.S. Byther. 1992. Apple anthracnose: Bulls-eye rot. Washington State Univ. Ext. Bul. 0940.

European and Mediterranean Plant Protection Organization. 2017. Neofabraea malicorticis distribution. 27 Mar. 2017. <https://gd.eppo.int/taxon/PEZIMA/ distribution>.

Garton, W.J., L.W. DeVetter, M. Mazzola, and C.A. Miles. 2018a. A review of Neofabraea malicorticis biology and management of anthracnose canker in apple orchards in the maritime Pacific Northwest. J. Amer. Pomol. Soc. 72:113-121.

Garton, W.J., M. Mazzola, N. Dasgupta, T.R. Alexander, and C.A. Miles. 2018b. Efficacy of excision, cauterization, and fungicides for management of apple anthracnose canker in maritime climate. HortTechnology 28:728-736.

Hewitt, H.G. 1998. Fungicides in crop protection. CABI, Wallingford, UK.

Hortová, B., D. Novotny, and T. Erban. 2014. Physiological characteristics and pathogenicity of eight Neofabraea isolates from apples in Czechia. Eur. J. Hort. Sci. 79:327-334.
Kienholz, J.R. 1939. Comparative study of the apple anthracnose and perennial canker fungi. J. Agr. Res. 59:635-665.

Miller, E.V. 1932. Some physiological studies of Gleosporium perennans and Neofabraea malicorticis. J. Agr. Res. $45: 65-77$.

Moulton, G.A., C.A. Miles, J. King, and A. Zimmerman. 2010. Hard cider production and orchard management in the Pacific Northwest. Washington State Univ. Ext. Publ. PNW621.

Powell, D., B. Johnson, and E.G. Sharvelle. 1970. Diseases of apples and pears in the Midwest. North Central Reg. Ext. Publ. 16:4.

Pscheidt, J.W. and C.M. Ocamb. 2017. Apple (Malus spp.) anthracnose (bull'seye rot). 23 Mar. 2017. <https:// pnwhandbooks.org/plantdisease/hostdisease/apple-malus-spp-anthracnosebulls-eye-rot $>$.

Rahe, J.E. 1997a. Anthracnose canker of apples: Put away the sprayer and get out the knife and brush. Qrtly. Nwsl. BC Fruit Testers Assn. Cider Press 10:6-9.

Rahe, J.E. 1997b. Failure of fungicides to control anthracnose canker of apple. Can. J. Plant Pathol. 19:231-232 (abstr.).

Rahe, J.E. 2010. Anthracnose canker webinar. 23 Mar. 2017. <http:// fruitgrowersnews.com/news/anthracnosewebinar-educates-growers $/>$.
Senula, A. 1985. Untersuchugen zur morphology und physiologie von Cryptosporiopsis malicorticis (Cordl). Nannf. und Phyctaena vagabundha Desm. Arch. Phytopathol. Pflanzenschutz 21:273-286.

Spotts, R.A. and B.B. Peters. 1982. The effect of relative humidity on spore germination of pear decay fungi and d'Anjou pear decay. Acta Hort. 124:75-78.

Spotts, R., K. Seifert, K. Wallis, D. Sugar, C.L. Xiao, M. Serdani, and J. Henriquez. 2009. Description of Cryptosporiopsis kienholzii and species profile of $\mathrm{Neo}^{-}$ fabraea in major pome fruit growing districts in the Pacific Northwest USA. Mycol. Res. 113:1301-1311.

Weber, R.W.S. and G. Palm. 2010. Resistance of storage rot fungi Neofabraea perennans, N. alba, Glomerella acutata and Neonectria galligena against thiophanatemethyl in northern German apple production. J. Plant Dis. Prot. 117:185-191.

Washington State University. 2017. AgWeatherNet monthly weather data for WSU Mt Vernon station. 5 June 2017. <http://weather.wsu.edu/?p=93150>.

Zang, R., L. Huang, and C.L. Xiao. 2011. Species of Neofabraea responsible for anthracnose canker of apple trees in western Washington State. Phytopathology 101: S251-S255 (abstr.). 